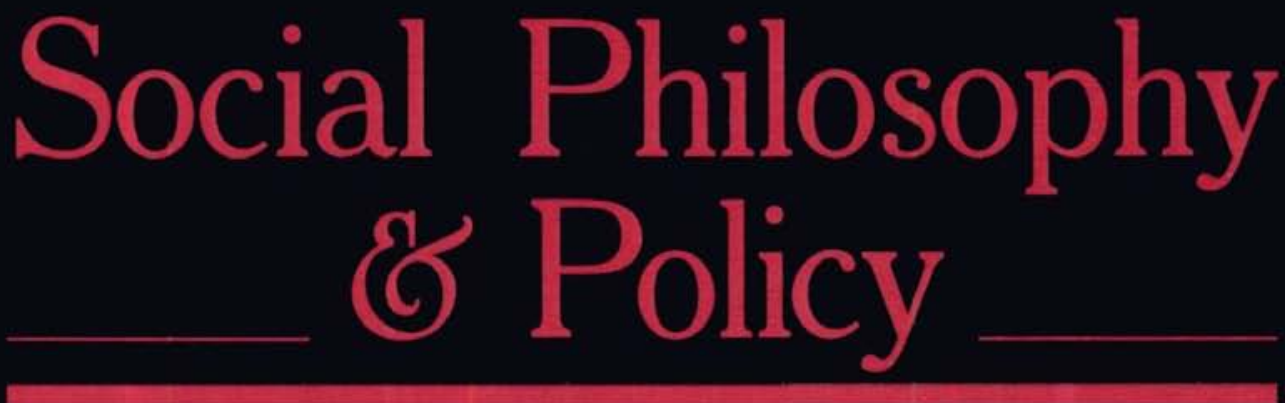

\title{
The Right to Privacy
}

\section{CONTENTS}

RICHARD A. EPSTEIN

LLOYD L. WEINREB

R. G. FREY

ALEXANDER ROSENBERG

RICHARD J. ARNESON

H. TRISTRAM ENGELHARDT, JR.

MARK TUSHNET

SCOTT D. GERBER

DAVID FRIEDMAN

JUDITH WAGNER DECEW

A. M. CAPRON

TOM L. BEAUCHAMP

FREDERICK SCHAUER
Deconstructing Privacy: And Putting It Back Together Again

The Right to Privacy

Privacy, Control, and Talk of Rights

Privacy as a Matter of Taste and Right

Egalitarian Justice versus the Right to Privacy

Privacy and Limited Democracy: The

Moral Centrality of Persons

Legal Conventionalism in the U.S.

Constitutional Law of Privacy

Privacy and Constitutional Theory

Privacy and Technology

The Priority of Privacy for Medical Information

Genetics and Insurance: Accessing and Using Private Information

The Right to Privacy and the Right to Die 


\section{Social Philosophy \& Policy}

ISSN 0265-0525

Editor: Ellen Frankel Paul

Associate Editors: Fred D. Miller, Jr., and Jeffrey Paul

Managing Editor: Matthew Buckley

Social Philosophy and Policy Center

David Braybrooke

University of Texas, Austin

Baruch Brody

Rice University

Allen Buchanan

University of Arizona

James Buchanan

Buchanan Center for Political Economy, George Mason University

Jules Coleman

Yale University

Jack Douglas

University of California, San Diego

Richard A. Epstein

University of Chicago Law School

James Fishkin

University of Texas, Austin
Editorial Board

Antony G.N. Flew
University of Reading (Emeritus)
Martin Golding
Duke University
John Gray
London School of Economics and
Political Science
Gilbert Harman
Princeton University
Seymour Martin Lipset
George Mason University and
Hoover Institution, Stanford University
Eric Mack
Tulane University
Harvey Mansfield, Jr.
Harvard University

Wallace I. Matson

University of California, Berkeley

Jan Narveson

University of Waterloo

Robert Nozick

Harvard University

Nicholas Rescher

University of Pittsburgh

David Sidorsky

Columbia University

Hillel Steiner

University of Manchester

James Q. Wilson

University of California,

Los Angeles

Leland B. Yeager

Auburn University

Social Philosophy $\mathcal{E}$ Policy is an interdisciplinary journal with an emphasis on the philosophical underpinnings of enduring social policy debates. Each issue is dedicated to a particular theme chosen by the editors, with the advice of the editorial board, designed to appeal to both academic specialists and a broader scholarly audience. While not primarily a journal of policy prescriptions, several contributions to each issue will typically connect theory with practice. The editors encourage and actively pursue diversity of viewpoints of contributors. Diversity is also encouraged by selecting authors from among different disciplines, especially philosophy, economics, political science, and the law. Readers' suggestions for future themes are always welcome, as are inquiries about the topics of issues already planned.

Editorial Office: Social Philosophy and Policy Center, Bowling Green State University, Bowling Green, $\mathrm{OH} 43403$, USA.

Publishing, Subscription, and Advertising Information: See inside back cover. Copyright (C) 2000 Social Philosophy and Policy Foundation

All rights reserved. No part of this publication may be reproduced, in any form or by any means, electronic, photocopying or otherwise, without permission in writing from Social Philosophy $\mathcal{E}$ Policy. Photocopying information for users in the USA: The Item-Fee Code for this publication (0265-0525/00 \$9.50) indicates that copying for internal or personal use beyond that permitted by Sec. 107 or 108 of the U.S. Copyright Law is authorized for users duly registered with the Copyright Clearance Center (CCC) Transaction Reporting Service, provided that the appropriate remittance is paid directly to: CCC, 222 Rosewood Drive, Danvers, MA 01923. Specific written permission must be obtained from Social Philosophy $\&$ Policy for all other copying. 


\section{CONTRIBUTORS}

Richard A. Epstein is James Parker Hall Distinguished Service Professor of Law at the University of Chicago. He is the author of Forbidden Grounds: The Case against Employment Discrimination Laws (1992), Simple Rules for a Complex World (1995), Mortal Peril: Our Inalienable Right to Health Care? (1997), and Principles for a Free Society: Reconciling Individual Liberty with the Common Good (1998). He is an editor of the Journal of Law and Economics and a member of the American Academy of Arts and Sciences.

Lloyd L. Weinreb is Dane Professor of Law at Harvard Law School, where he has taught since 1965 . He teaches and writes in the areas of jurisprudence, moral and political philosophy, criminal law and procedure, and intellectual property. His books include Denial of Justice (1977), Natural Law and Justice (1987), and Oedipus at Fenway Park: What Rights Are and Why There Are Any (1994). He is currently working on a book about the nature of legal reasoning.

R. G. Frey is Professor of Philosophy at Bowling Green State University and a Senior Research Fellow at the Social Philosophy and Policy Center at Bowling Green State University. He has written numerous articles and books in moral and political philosophy, eighteenth-century British moral philosophy, and applied ethics. Most recently, he is the coauthor of $E u_{-}$ thanasia and Physician-Assisted Suicide (with Gerald Dworkin and Sissela Bok, 1998).

Alexander Rosenberg is Professor of Philosophy at the University of Georgia. He is the author of many books in the philosophy of biology and the philosophy of economics, including Economics-Mathematical Politics or Science of Diminishing Returns? (1993) and Instrumental Biology or the Disunity of Science (1995). His most recent book is Darwinism in Philosophy, Social Science, and Policy (1999). He has received fellowships from the National Science Foundation, the American Council of Learned Societies, and the John Simon Guggenheim Foundation.

Richard J. Arneson is Professor of Philosophy at the University of California at San Diego, where he was department chair from 1992 to 1996 . He has held visiting appointments at the California Institute of Technology, University of California at Davis, Yale University, and the Research School of Social Sciences, Australian National University. He writes mainly on social and political philosophy, with an emphasis on contemporary theories of justice. 
H. Tristram Engelhardt, Jr., is Professor of Medicine at Baylor College of Medicine, Professor of Philosophy at Rice University, and Member of the Center for Medical Ethics and Health Policy at the Baylor College of Medicine. He is the editor of the Journal of Medicine and Philosophy and of the book series Philosophical Studies in Contemporary Culture. He is also coeditor of the journal Christian Bioethics: Non-Ecumenical Studies in Medical Morality, and of the book series Philosophy and Medicine. His recent publications include Bioethics and Secular Humanism (1991) and The Foundations of Bioethics, $2 \mathrm{~d}$ ed. (1996).

Mark Tushnet is Carmack Waterhouse Professor of Constitutional Law at the Georgetown University Law Center. His books include Red, White, and Blue: A Critical Analysis of Constitutional Law (1988), Making Constitutional Law: Thurgood Marshall and the Supreme Court, 1961-1991 (1997), and Taking the Constitution Away From the Courts (1999). He has written widely in the fields of constitutional law, constitutional theory, and U.S. legal history.

Scott D. Gerber is Senior Research Scholar in Law and Politics at the Social Philosophy and Policy Center at Bowling Green State University. He is the author of To Secure These Rights: The Declaration of Independence and Constitutional Interpretation (1995) and First Principles: The Jurisprudence of Clarence Thomas (1999), and is also the editor of Seriatim: The Supreme Court before John Marshall (1998).

David Friedman is Professor of Law and Professor of Economics at Santa Clara University. His current interests are in the application of economics to law and the implications of new technologies for law, economics, and society. His previous books include Price Theory: An Intermediate Text, $2 \mathrm{~d}$ ed. (1990) and Hidden Order: The Economics of Everyday Life (1996). His next book, Law's Order: What Economics Has to Do with Law and Why It Matters, is forthcoming from Princeton University Press.

Judith Wagner DeCew is Professor of Philosophy and Associate Dean of the College at Clark University. She has previously taught at the Massachusetts Institute of Technology, and has been a Research Fellow at the Bunting Institute and at Harvard Law School. She is the coeditor of Theory and Practice (with Ian Shapiro, 1995) and the author of In the Pursuit of Privacy: Law, Ethics, and the Rise of Technology (1997). She is also the SecretaryTreasurer of the American Society for Political and Legal Philosophy.

A. M. Capron holds a University Professorship at the University of Southern California, where he is also Henry W. Bruce Professor of Law and Co-Director of the Pacific Center for Health Policy and Ethics. In addition to serving on the National Bioethics Advisory Committee and the Joint Commission for Accreditation of Healthcare Organizations, Professor Ca- 
pron has written widely on the ethical and legal issues raised by developments in molecular genetics.

Tom L. Beauchamp is Professor of Philosophy at Georgetown University and is a Senior Research Scholar at the Kennedy Institute of Ethics. His research interests include applied ethics (particularly biomedical ethics and business ethics) and the history of modern philosophy. He is the coauthor of A History and Theory of Informed Consent (with Ruth R. Faden and Nancy M. P. King, 1986) and Principles of Biomedical Ethics, 4th ed. (with James F. Childress, 1994). He is also one of three editors of the Clarendon Hume, a critical edition of the works of David Hume.

Frederick Schauer is Frank Stanton Professor of the First Amendment and Academic Dean at the John F. Kennedy School of Government, Harvard University. He is the author of Free Speech: A Philosophical Enquiry (1982), Playing by the Rules: A Philosophical Examination of Rule-Based DecisionMaking in Law and in Life (1991), and numerous articles on legal and constitutional theory. His work is the subject of Linda Meyer's collection, Rules and Reasoning: Essays in Honour of Fred Schauer (1999). 